\title{
119 全眸度レべルにおける物体色の
}

等 価 明度と飞の決定 $九$ 万

池田光男

（東京工業大学總合理工）
芦澤昌子

（青葉学園短大）

ここで私たちが取り扱うのは明るさを判定基準としたときの物体表面の等価明度である。 それを $0.011 \times$ から $10001 \times$ までの、いわゆる暗所視、薄明視、明所視の照度レベルに わたって検討する。

䁚定対象として物体表面を採用したのは実用的意味を考えてのことである。とくに照度 レベルの低い視境では、低緟度のものは全て物体表面である。自ら光を発する光源は当 然輝度は高くなり、その明るさ評価には暗所視や薄明視の視賞特性を逼用する必要はなく なる。薄明視レベルで明るさを帮価したいのはほとんどの揚合物体表面である。

等価明度とは光源色（あるいは煇面色）の坦合の等価戦度に対応するもので、物体表面 の明るさにマッチしたときのグレースケールの明度のことである。つまり、物体表面と等 しい明るさを呈するグレースケールの明度である。この尺度は别にグレースケールでなく ともよい。たとえは触面色の堨合は570 $\mathrm{nm}$ の単色光を採用する人もいるように、物体色 の昜合で黄色のスケールを用いてもかまわない。しかしここでは無彩色のグレースケー ルを探用した。

もう一点 述べておきたいのは明るさを判断基準にしたことの意味である。これについ ては既に何回も機会ある毎に述べてきたか、薄明視になるととくに重要なので再度言及し

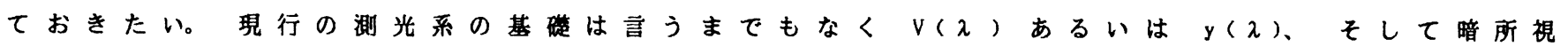
では $v^{\prime}(\lambda)$ でる。 $v^{\prime}(\lambda)$ は别にして、 $v(\lambda)$ を決めたときの判定基準はフリッカ一 知覚であった。したがって梗言すれは、見行の溉光系は光のちらつきということが課題で あるときのみ意味を持つのである。その後の研究で、視覚の分解能あるいは視力との相閣 もよいことが分かってきているので、もし視作業が分解能に関係するようなものであると 照度や解度などの測光量はきわめて䢱当ということになる。しかし現実にはそのような視 作業はこく稀である。たとえは嬂場で文字を䛃むという仕事でも、文字の細部の分解が問 題になるようなことはまずないむしろ字のコントラスト、明るさのコントラストの方が 大切である。照明された部屋の中の視環境の評価でも、やはり明るさが問題である。最近 話題になるライトアップの照明でも、大切なのは明るさである。分解能よりは明るさの方 が胃実では重要な意味を持つことが多い。これが薄明視になるとさらにその㑯向が強まる。 薄明視では人間の視力は低下するので、こまかい物を見ることは重要ではなくなり、物が ある、何がある、というようなことが大切になってくる。その判定には明るさこそ重要な のである。

\section{[実箕]}

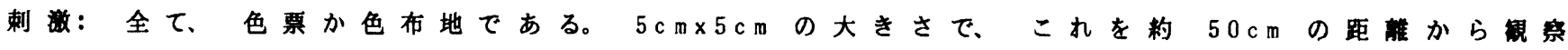
する。

等価明度： 明度 2.5 から 9.5 までをカパーする 15 枚のグレースケールを用い、刺激の 明るさに丁度一致するグレースケールを求める。その明度を等価明度と定義する。ひっった りのグレースケールがない㧹合は内㨂、外捅も可である。

照度レベル：実踰は全て照度のコントロールできるメソピックルームで行う。採用した照

Equivalent lightness of object colors at various llluminancelevels and its

theoretical explanation.

Mitsuo Ikeda and Shoko Ashizawa 
度レベルは $0.011 \times$ から $10001 \times$ まで、 10 段階である。

被㯃者: 色賞正常者数名。

[ 結 果]

図 $1 \mathrm{a} 、 \mathrm{~b}$ に、黄と青の㧹合の例を示す。それそれ色の濃さの異なるもの4枚を対象と している。黄の色布地では明るいところでは等価明度は変化しない。暗くなると徐々に低 下する。青の色布地では明るいところでは照度ががると等価明度も下かる。しかしさら に暗くなると等価明度が上昇する。いすれの色でも照度レベルによって等価明度が大をく 変わることを示している。

[ 説 明 ]

これらの結果を見て私たちは明るさを決定するものは白みの成分と色みの成分であると 考える。視覚のメカニスムから言うと、度チャンネルの出力と色チャンネルの出力であ る。色みの成分は当然ながら錐体が的いているときのみ存在する。白みの成分は桿体によ っても生じるので、照度レベルが下がっていくと錐体による白みの成分は娍少していき、 代わって桿体による白みの成分が増大していく。

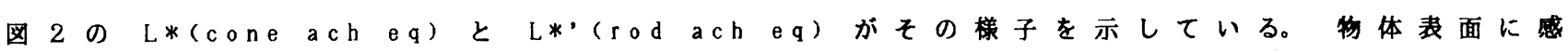
じる明るさは両者が合されたものであるから、

$L *(a c h$ eq $)=L *($ cone acheq) $+L *$ ( r od acheq)

で表すことが出来る。

色みの成分は錐体の的くときのみ存在するが、照度レベルが增大するにつれて大きくな ると仮定する。图 2 の点線で示した L*( chr eq) がそれである。これが $\mathrm{L} *(\mathrm{ach}$ e q $)$ にプ ラスされて最䊏的な $\mathrm{L} *(\mathrm{eq})$ が決定される。すなわち

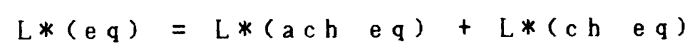

であり、四 2 の太線でこれを示している。

このように考えると今回の私たちの結果もおおょそ説明かつく。
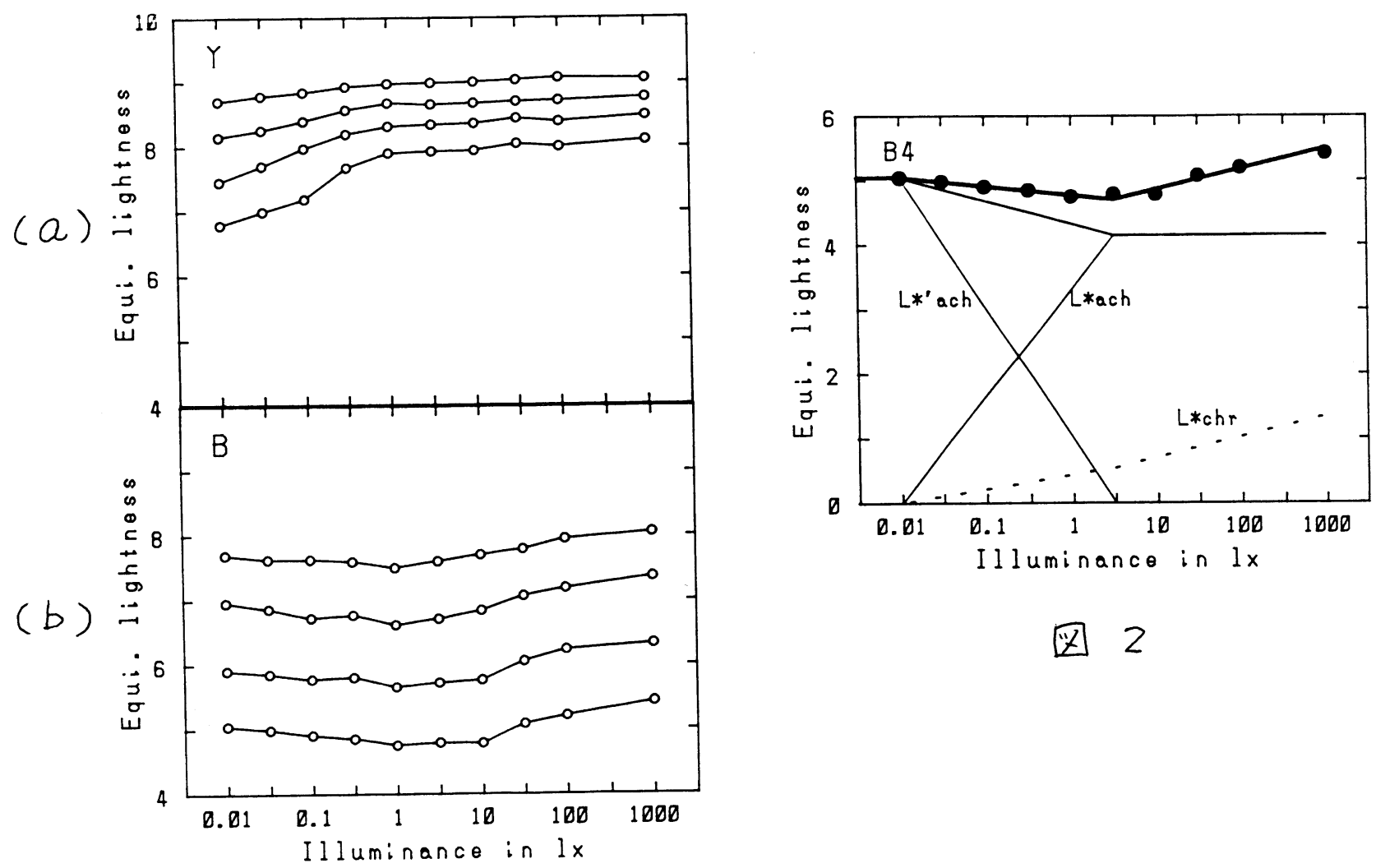

回 2

四 1 